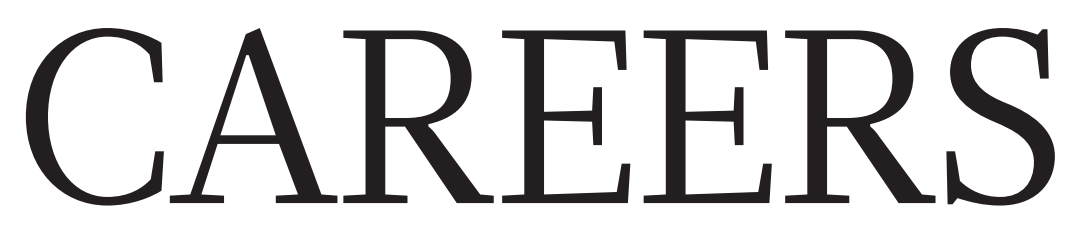

TURNING POINT Bioorganic chemist aims to pay his success forward $\mathbf{p . 4 1 5}$
INNOVATION University support boosts productivity for academic inventors $\mathbf{p . 4 1 5}$
NATUREJOBS For the latest career

listings and advice www.naturejobs.com

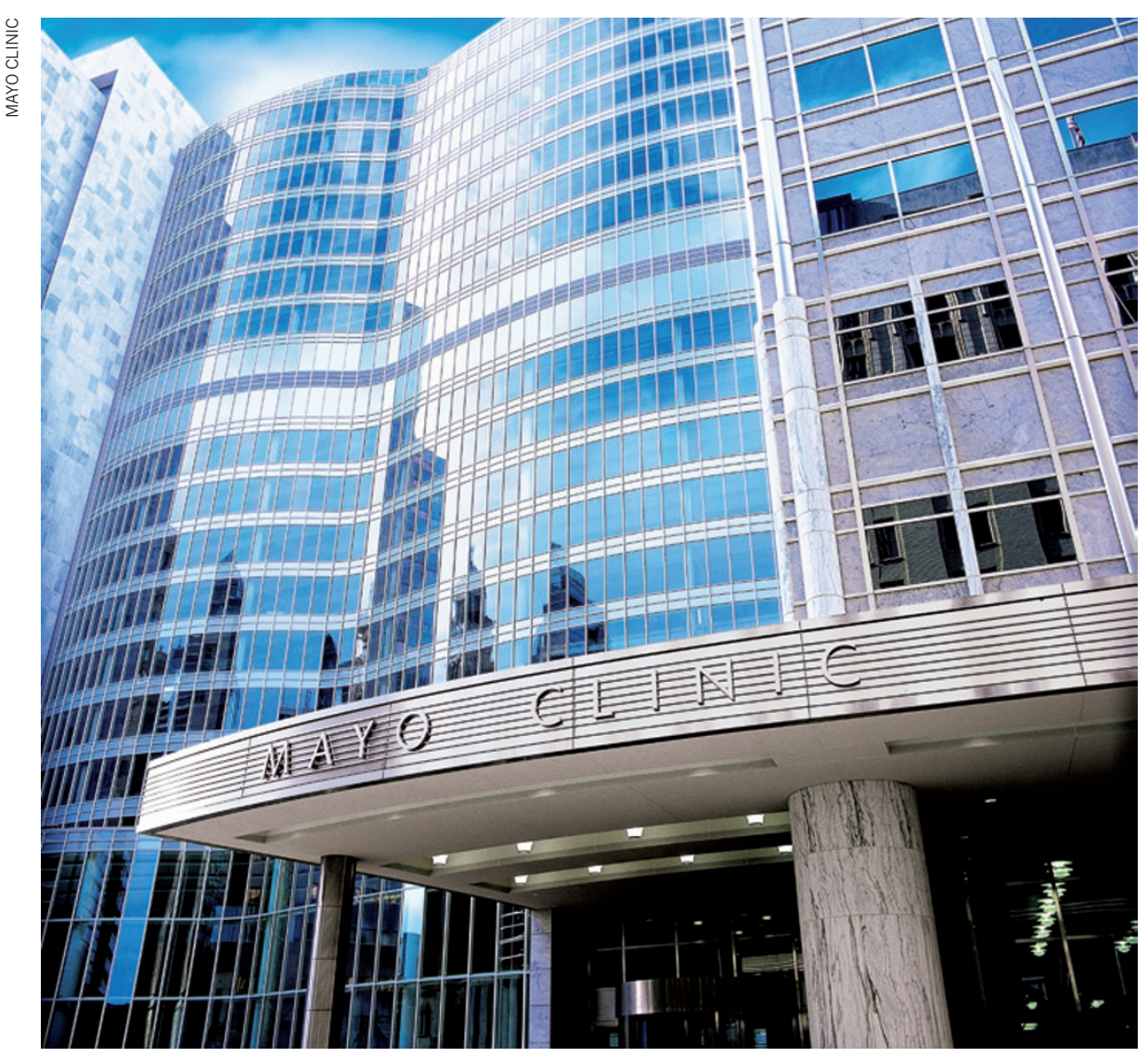

The Mayo Clinic in Rochester, Minnesota, is a powerhouse of biomedical research.

MINNESOTA

\title{
Medicine and materials
}

\section{Minnesota made its mark in medical devices and has green potential. But state funding woes could hamper progress.}

\section{BY PAUL SMAGLIK}

$\mathrm{I}$ n 1949, Earl Bakken co-founded a medical-equipment repair company out of his garage in Minneapolis, Minnesota. Nearby, C. Walton Lillehei was pioneering cardiac surgery at the University of Minnesota. The physician, who successfully performed the world's first open-heart surgery in 1952, recognized that about $1 \%$ of children are born with holes in their hearts, and he wanted to find a way to close those holes. To keep the patient's blood flowing while the heart recovered from surgery, Lillehei first tried circulating the blood between the child and their parent, then switched to a plug-in pacemaker. After a power cut in October 1957, Lillehei grew concerned about losing patients during outages.
So he asked Bakken to devise a battery-operated system. Bakken's company grew rapidly, first selling the external pacemaker that he came up with, then developing and marketing an implantable version, as well as defibrillators and other equipment. Medtronic is now based in Fridley, Minnesota, and has 43,000 employees worldwide - with about 10,000 in Minneapolis-St Paul alone.

Entrepreneurial activity in Minnesota has enabled more than 100 medical-device companies to emerge since the middle of last century - many of them direct spin-offs from Medtronic. The industry's growth has been fuelled by intellectual property and research expertise from the University of Minnesota and the Mayo Clinic in Rochester (see 'A promising partnership'). Those successes have sparked burgeoning biomedical and green industries in the region, helping job growth. But a paucity of state funding could be an obstacle - a long-planned major science park has been put on hold, and state support for entrepreneurial ventures is waning.

\section{TRIGGERING DEVICES}

In terms of job growth, "the big horse pulling the sleigh is the device industry", says Dale Wahlstrom, chief executive of the BioBusiness Alliance of Minnesota in St Louis Park. But many of the new jobs springing up in Minnesota are at small companies dealing in biologics and biopharmaceuticals, animal health, food, renewable energy and renewable materials. This signals an increase in opportunities: Wahlstrom says that the number of $\mathrm{PhD}$-level life-sciences jobs in the state has grown from 28,889 in 1997 to a projected 35,459 now.

Challenges loom, however. In 2008, the state legislature approved the University of Minnesota's Biomedical Discovery District, a US\$292-million, 65,000-square-metre cluster of research facilities in Minneapolis. The last stage of construction began this May. But the chances of the university receiving funding for a 130,000-square-metre science park that it proposed five years ago are uncertain. Neither the university nor the state government has committed the money necessary for the project to qualify for a federal loan - the deadline for which is coming up. The state government shut down on 1 July, when Governor Mark Dayton and the state legislature failed to agree on fixes to an estimated \$5-billion state budget deficit; the hold-up further jeopardizes the science park. (As Nature went to press, a budget resolution was imminent.) 
> Minnesota's entrepreneurial environment is also something of a dichotomy. A report by the Kauffman Foundation in Kansas City, Missouri (The 2010 State New Economy Index, Kauffman Foundation, 2011) ranked the state 7 th in the country for industrial investment in research, but only 39 th for non-industry investment, including federal and state funding, and 42nd for entrepreneurial activity.

Still, the region shows potential in the medical-device sector and life-sciences ventures. The Kauffman report ranked Minnesota eighth for the percentage of scientists and engineers in the workforce, eighth for the number of advanced degrees among workers and sixth in terms of the percentage of jobs that were managerial, professional and technical positions requiring at least two years of university education.

\section{CROSSING OVER}

Wahlstrom notes that the state's life-sciences specialities are increasingly diversifying and expanding. Companies that make biomaterials using clean chemistry are starting to have a role in developing medical devices. $3 \mathrm{M}$, a materials company based in Maplewood, Minnesota, has a medical-device division, and Cargill, a food company based in Minneapolis, helped to pioneer green chemistry by creating Natureworks,

a biopolymer manufacturer based in Minnetonka, in 1997.

The Mayo Clinic and the University of Minnesota both feed talent into companies big and small, and some Minnesota entrepreneurs who made their fortunes with legacy companies are providing funds for start-up firms. Steve Oesterle, senior vice-president for medicine and technology at Medtronic, says that Minnesota has a "deep well" of such angel investors, who are encouraged by a state tax credit introduced last year.

Entrepreneur Manny Villafana is one successful businessman who is giving back. He created seven medical-device companies after leaving Medtronic in 1971 and influenced others. For example, Vascular Solutions in Minneapolis is a spin-off from another of his companies, ATS Medical, which Medtronic purchased last year. Vascular Solutions develops, manufactures and markets devices that aid in peripheral heart surgery. The company has about 350 employees, many of them biomedical engineers and material scientists, and has been growing by about 20 people a year.

Minnesota's science jobs aren't all in the medical-device field. Talent, money and intellectual property are also flowing into green chemistry from the state's larger companies and academic

\section{DIABETES DIVIDENDS}

\section{A promising partnership}

Two of Minnesota's biggest research institutions are hoping that past success in collaboration will bode well for future ambitions. In 2004, the state started funding the Minnesota Partnership for Biotechnology and Medical Genomics, hoping that a joint venture between traditional rivals the University of Minnesota in Minneapolis and the Mayo Clinic in Rochester would attract federal money. So far, it has worked, with a state investment of more than US $\$ 90$ million drawing over $\$ 100$ million in federal grants.

Now the institutions want to run a similar project, but with a focus on diabetes. They aim to raise even more money, in what administrators call a moon shot - a bid to make substantial advances in treating, preventing and curing diabetes over the next 10 years. It could also mean substantial opportunities for diabetes researchers.

Launched last October, the state's 'Decade of Discovery' project aims to garner up to $\$ 200$ million in money from the state government, private companies and philanthropic organizations, and an equivalent amount from the National Institutes of Health and other US government funders. That will provide hundreds of jobs in diabetes research, treatment and prevention. Victor Montori, Mayo's director of the Decade of Discovery, says that the diabetes effort was intentionally designed as a job-creation programme, adding that investment - and jobs - will come not just in biomedical research, but also in health insurance, clinics, community organizations and the business community.

Tim Mulcahy, vice-president for research at the University of Minnesota, says that the project is well positioned to attract money. It will benefit from a wealth of basic research at the university, clinical expertise at Mayo, input from the medical-device community, and interactions with public-health and public-policy experts. But even so, Eric Wieben, a biochemist at Mayo, admits that fund-raising will be a challenge, given the state's - and the nation's - current economic condition. "We are working with a two-year election cycle," he says. "We need to show that there is a return on this."

Wieben says that the two institutions can point to the earlier successes of the Minnesota Partnership to show that the diabetes programme will work. Mayo has added hundreds of research positions since the partnership's inception, despite the national recession. P.S. institutions. Chemical engineers, molecular biologists and materials scientists are building firms that aim to reduce waste and pollution in fuels, materials and chemical processing. Some of these companies have attracted venture capital despite the slow economic recovery, allowing them to recruit scientists.

For example, BioAmber of Plymouth, Minnesota - a Cargill spin-out company - aims to turn agricultural crops into chemicals that can replace petroleum-based plastics. It raised $\$ 45$ million this year, and is looking to build a production plant that will employ fermentation engineers, molecular biologists and analytical chemists. Jeff Warwick, BioAmber's director of analytical chemistry, says that the company plans to hire ten scientists this year. BioAmber intends to draw from the chemistry talent pools at Cargill, $3 \mathrm{M}$ and the University of Minnesota. "We will aggregate more and more resources in terms of people, so it's important that we have local connections," says Warwick. Another Minnesota biomaterials company, Segetis in Golden Valley, has 25 employees, and last month raised the money to expand to as many 100 when its production plant opens later this year, says a company spokeswoman.

The state seems poised to emerge as a player in green technology, says Doug Cameron, founder and managing director of Alberti Advisors, a firm based in Plymouth that matches venture capital to companies. He points to BioAmber's venture-capital success, as well as to increasing sales at Segetis and Natureworks and the purchase of a biofuels plant in Luverne, Minnesota, by Gevo of Englewood, Colorado.

\section{CHALLENGES AFOOT}

But Minnesota may find that a legacy of medical devices and a few successful ventures don't necessarily translate into overall success for sciences start-ups. According to Tim Mulcahy, vice-president of research at the University of Minnesota, the state needs to take steps to nurture innovation and entrepreneurship - and attract new jobs. This includes helping earlystage companies find federal support, helping entrepreneurs network with investors, and connecting academia with industry to establish centres of research excellence. These recommendations were part of a report (Minnesota Science and Technology Authority Strategic Plan: Turning Ideas into Jobs Minnesota Science and Technology Authority, 2011) that Mulcahy and others drafted. Legislators responded favourably at first, says Mulcahy, but state budget battles have pushed such initiatives aside. Although the state has invested in innovation, it does not have a cohesive, coordinated plan, he says. Probable budget cuts will make addressing the elements of an innovation framework more difficult. "All of these things," says Mulcahy, "need to be in place in order to end up with jobs."

Paul Smaglik is a science writer based in Milwaukee, Wisconsin. 